\title{
TABEL KONTINGENSI UNTUK MENGETAHUI HUBUNGAN ANTARA JENIS PENYAKIT, JENIS KELAMIN, USIA, LAMA RAWAT DAN KEADAAN KELUAR PASIEN
}

\author{
Wara Pramesti \\ Universitas PGRI AdiBuana Surabaya
}

\begin{abstract}
ABSTRAK
Tabel kontingensi dapat digunakan untuk melihat hubungan dua peubah kategorik. Dari tabel kontingensi ini dapat dibuat kesimpulan apakah ada hubungan antara satu variabel dengan variabel lainnya.

Data jenis penyakit, jenis kelamin, usia pasien, lama rawat dan keadaan keluar pasien diambil dari rumah sakit Siti Khadijah Sepanjang yang selanjutnya dengan menggunakan uji Chi-Square pada table Kontingensi dapat diketahui hubungan antara jenis penyakit dengan jenis kelamin, jenis penuyakit dengan usia dan jenis penyakit dengan lama rawat serta jenis penyakit dengan keadaan keluar pasien. Hasil analisis menunjukkan bahwa jenis kelamin dan usia pasien rawat inap tidak saling bebas dan keduanya saling berkaitan. Ketergantungan antara jenis penyakit dengan jenis kelamin yang paling signifikan adalah jenis penyakit GE atau diare, gastritis dan diabetes mellitus. ada jenis penyakit tertentu yang tidak signifikan hubungannya dengan usia pasien yaitu untuk jenis penyakit gastritis pada usia remaja, penyakit hypertensi pada usia dewasa, penyakit pneumonia pada usia tua dan lansia, penyakit step pada usia anak - anak dan juga penyakit FUO (demam) pada usia dewasa. Untuk hal dependensi yang paling signifikan antara lama rawat dengan keadaan keluar pasien adalah lama rawat lebih dari 2 minggu dan keluar dalam keadaan di rujuk ke rumah sakit lain dan meninggal.
\end{abstract}

Kata Kunci : Tabel Kontingensi, Uji Chi Square

\section{Pendahuluan}

Uji Chi-square pada tabel kontingensi merupakan suatu metode statistik yang digunakan untuk menguji hipotesis dua variabel saling bebas (independensi), (Walpole, 1995). Independensi diartikan sebagai probabilitas suatu kejadian yang tidak tergantung dari kejadian lain. Dari jalan ini akan diperoleh suatu asumsi yang keputusannya dapat dipertahankan bahwa beberapa kondisi dapat diterima. Asumsi - asumsi tersebut adalah :

1. Data terdiri atas sebuah sampel acak sederhana berukuran dari suatu populasi yang diamati.

2. Hasil pengamatan dalam sampel dapat diklasifikasikan secara silang menurut dua kriteria, sehingga setiap hasil pengamatan memenuhi salah satu dan hanya satu arah dari setiap kriteria. Kriteria disini adalah semua variabel yang diminati dalam situasi yang dihadapi.

Tabel kontingensi memuat data yang diperoleh dari sampel random sederhana dan diatur berdasarkan baris dan kolom. Baik baris maupun kolom masing - masing terbagi dalam kriteria - kriteria. Nilai - nilai data pada tabel kontigensi merupakan frekuensi observasi yang biasa dinotasikan dengan fo.

Uji chi-square didasarkan atas kesesuaian antara frekuensi amatan dengan frekuensi harapan yang diperoleh. Bila frekuensi harapan dekat dengan nilai frekuensi amatan maka nilai $x^{2}$ akan kecil, yang berarti bahwa kedua variabel independen. Dan bila nilai frekuensi harapan cukup berbeda dengan nilai frekuensi amatan maka nilai $x^{2}$ akan besar, yang berarti kedua variabel tersebut adalah dependen. Nilai standar residual dapat juga digunakan untuk mengetahui apakah kedua variabel independen. Selanjutnya uji Chi Square ini akan digunakan untuk mengetahui karakteristik pasien di instalansi rawat inap rumah sakit Siti Khodijah Sepanjang Sidoarjo dan menentukan pola hubungan antara jenis penyakit dengan usia, jenis penyakit dengan jenis kelamin, dan lama rawat dengan keadaan keluar pasien rawat inap.

\section{Tinjauan Pustaka}

\subsection{Statistik Deskriptif}

Statistik Deskriptif adalah statistik yang digunakan untuk mendeskripsikan atau menggambarkan tentang data yang disajikan dalam bentuk tabel, diagram, ukuran tendensi sentral, ukuran penempatan dan ukuran penyimpangan. Akan tetapi, pada statistik deskriptif tidak dapat menghasilkan atau melibatkan penarikan kesimpulan yang berlaku secara generalisasi (bersifat umum). 


\subsection{Statistik Inferensial}

Statistik Inferensia atau statistik probabilitas adalah suatu alat pengumpul data, pengolah data, penarik kesimpulan, pembuat tindakan berdasarkan analisis data yang dikumpulkan atau dapat juga diartikan sebagai statistik yang digunakan untuk menganalisa data sample dan hasilnya digunakan kesimpulan untuk populasi.

\section{Uji Chi-Square}

Secara umum tabel kontingensi dapat dilihat pada Tabel 2.1. Tabel Kontingensi tersebut menggambarkan bahwa sejumlah $N$ obyek penelitian atau pengamatan terbagi dalam 2 kategori. Besaran $O_{i j}$ adalah jumlah obyek pengamatan dari kategori i dalam peubah baris dan kategori j dalam peubah kolom. Dalam hal ini $b_{i}$ adalah jumlah frekuensi dalam baris ke-i, $k_{i}$ jumlah frekuensi dalam kolom ke-j dan $\mathrm{N}$ adalah jumlah obyek total dalam seluruh pengamatan. Uji yang dilakukan pada table kontingensi adalah untuk menguji apakah ada ketergantungan antara dua kategori yang berbeda dari katagori baris dan katagori kolom.

\section{Langkah Uji Chi-Square Untuk Tabel $b \times \mathbf{k}$}

Syarat awal dari analisis ini adalah obyek pengamatan $n$ besar. Sifat berikut ini digunakan sebagai dasar dalam melakukan uji $\mathrm{b} \times \mathrm{k}$ untuk tabel kontingensi.

Tabel 2.1. : Tabel Kontigensi

\begin{tabular}{|c|c|c|c|c|c|c|c|}
\hline \multirow{2}{*}{$\begin{array}{l}\text { Klasifikasi } \\
\text { Pertama }\end{array}$} & \multicolumn{6}{|c|}{ Klasifikasi Kedua } & \multirow[t]{2}{*}{ Jumlah } \\
\hline & 1 & 2 & $\ldots$ & $\mathrm{J}$ & $\ldots$ & $\mathrm{c}$ & \\
\hline 1 & $O_{11}$ & $O_{12}$ & $\ldots$ & $O_{1 j}$ & $\cdots$ & $O_{1 c}$ & $b_{1}$ \\
\hline 2 & $O_{21}$ & $O_{22}$ & $\cdots$ & $O_{2 j}$ & $\cdots$ & $O_{2 c}$ & $b_{2}$ \\
\hline$\ldots$ & $\ldots$ & $\ldots$ & $\ldots$ & $\ldots$ & $\ldots$ & $\ldots$ & $\ldots$ \\
\hline I & $O_{i 1}$ & $O_{i 2}$ & $\cdots$ & $O_{i j}$ & $\cdots$ & $O_{i c}$ & $b_{i}$ \\
\hline$\ldots$ & $\ldots$ & $\ldots$ & $\ldots$ & $\ldots$ & $\ldots$ & $\ldots$ & $\ldots$ \\
\hline $\mathrm{R}$ & $O_{r 1}$ & $O_{r 2}$ & $\cdots$ & $O_{r j}$ & $\cdots$ & $O_{r c}$ & $b_{r}$ \\
\hline Jumlah & $k_{1}$ & $k_{2}$ & $\ldots$ & $k_{j}$ & $\ldots$ & $k_{c}$ & $\mathrm{~N}$ \\
\hline
\end{tabular}

Keterangan :

$O_{i j} \quad=$ Variabel pengamatan

$b_{i} \quad=$ Banyaknya pengamatan dari baris $\mathrm{ke}-\mathrm{i}$

$k_{j} \quad=$ Banyaknya pengamatan dari baris $\mathrm{ke}-\mathrm{j}$

$\mathrm{N}=$ Banyaknya data yang diamati

Tabel 2.2 : Tabel Kontingensi Frekuensi Harapan

\begin{tabular}{|c|c|c|c|c|c|c|}
\hline \multirow{2}{*}{$\begin{array}{c}\text { Klasifikasi } \\
\text { Pertama }\end{array}$} & \multicolumn{7}{|c|}{ Klasifikasi Kedua } \\
\cline { 2 - 7 } & 1 & 2 & $\ldots$ & $\mathrm{J}$ & $\ldots$ & $\mathrm{C}$ \\
\hline 1 & $E_{11}$ & $E_{12}$ & $\ldots$ & $E_{1 j}$ & $\ldots$ & $E_{1 c}$ \\
\hline 2 & $E_{21}$ & $E_{22}$ & $\cdots$ & $E_{2 j}$ & $\ldots$ & $E_{2 c}$ \\
\hline$\ldots$ & $\ldots$ & $\ldots$ & $\ldots$ & $\ldots$ & $\ldots$ & $\ldots$ \\
\hline $\mathrm{I}$ & $E_{i 1}$ & $E_{i 2}$ & $\cdots$ & $E_{i j}$ & $\ldots$ & $E_{i c}$ \\
\hline$\ldots$ & $\ldots$ & $\ldots$ & $\ldots$ & $\ldots$ & $\ldots$ & $\ldots$ \\
\hline $\mathrm{R}$ & $E_{r 1}$ & $E_{r 2}$ & $\cdots$ & $E_{r j}$ & $\ldots$ & $E_{r c}$ \\
\hline
\end{tabular}

Keterangan :

$E_{i j}=$ Nilai frekuensi harapan 
Langkah - langkah pengujian chi-square adalah sebagai berikut :

1) Menentukan hipotesis nol :

$H_{0}$ : Kedua variabel independen

$H_{1}$ : Kedua varabel dependen

2) Menentukan frekuensi harapan $\left(E_{i j}\right)$ tiap sel data

$E_{i j}=\frac{b_{i} k_{j}}{N}$

$b_{i}=$ Banyaknya pengamatan dalam baris ke-i

$k_{j}=$ Banyaknya pengamatan dalam kolom ke-j

$\mathrm{N}$ = Banyaknya data yang diamati

3) Menghitung nilai chi-square $\left(x^{2}\right)$

$$
\begin{gathered}
x^{2}=\sum_{i=1}^{b} \sum_{j=1}^{k} \frac{(O i j-E i j)^{2}}{E i j} \\
O_{i j} \quad=\text { Nilai frekuensi amatan } \\
E_{i j} \quad=\text { Nilai frekuensi harapan }
\end{gathered}
$$

4) Menentukan daerah penolakan atau daerah kritis

$H_{0}$ ditolak bila:

$x^{2}>x^{2} \alpha(k-1)(b-1)$

Keterangan :

$\alpha \quad=$ Tingkat kesalahan yang diambil

$(k-1)(b-1)=$ derajat bebas

5) Kesimpulan

Bila hasil perhitungan berada dalam daerah kritis atau dapat juga dikatakan jika $x_{\text {hitung }}^{2}>x_{\text {tabel maka }}^{2}$ $H_{0}$ ditolak, yang berarti bahwa dua variabel tersebut tidak saling bebas (dependen). Dan jika sebaliknya, $x_{\text {hitung }}^{2}<x_{\text {tabel }}^{2}$ maka $H_{0}$ akan diterima yang berarti dua variabel tersebut saling bebas (independent).

\section{Metodologi Penelitian}

Populasi dalam penelitian ini adalah semua pasien rawat inap di rumah sakit Siti Khodijah Sepanjang. Sampel diambil secara proporsional berdasarkan jumlah pasien yang dirawat inap di rumah sakit Siti Khodijah Sepanjang tahun 2006.

Data yang digunakan dalam penelitian ini merupakan data sekunder yaitu data yang diambil secara tidak langsung, data yang diperoleh dalam bentuk yang sudah jadi dan sudah dikumpulkan serta diolah oleh pihak lain. Data dikumpulkan berupa jenis kelamin, jenis penyakit, keadaan pasien waktu keluar dari rumah sakit dan lama rawat inap.

\subsection{Variabel Dan Definisi Operasional Variabel}

1. Jenis Kelamin

Dalam hal ini jenis kelamin dari pasien rawat inap di rumah sakit Siti Khodijah dikelompokkan menjadi 2 kelompok, yaitu :

1). Laki - laki

2 ). Perempuan 
2. Jenis Penyakit

Untuk jenis penyakit yang diderita oleh pasien rawat inap di rumah sakit Siti Khodijah ada 10 kelompok, yaitu :

Tabel 3.1 Jenis Pengelompokan Penyakit

\begin{tabular}{|l|l|l|l|}
\hline 1. & GE atau penyakit diare & 6. & Faringitis \\
\hline 2. & DHF atau penyakit demam berdarah & 7. & Pnemonia \\
\hline 3. & Typhoid fever atau penyakit thypus & 8. & Hypertensi \\
\hline 4. & Gastritis & 9 & Febris convulsi atau penyakit step \\
\hline 5. & Diabetes mellitus & 10. & FUO atau penyakit demam \\
\hline
\end{tabular}

Tabel 3.2 Kelompok Usia Pasien Rawat Inap

\begin{tabular}{|l|l|l|}
\hline 1. & Balita & $(0-<5$ tahun $)$ \\
\hline 2. & Anak - anak & $(5-<15$ tahun $)$ \\
\hline 3. & Remaja & $(15-<25$ tahun $)$ \\
\hline 4. & Dewasa & $(25-<45$ tahun $)$ \\
\hline 5. & Tua & $(45-<65$ tahun $)$ \\
\hline 6. & Lansia & $(>65$ tahun $)$ \\
\hline
\end{tabular}

3. Keadaan Pasien Waktu Keluar

Dalam hal ini keadaan pasien waktu keluar dari pasien rawat inap rumah sakit Siti Khodijah dibedakan menjadi 4 kelompok, yaitu :

1) Sembuh

2) Rujuk

3) Pulang Paksa

4) Meninggal

4. Lama Rawat

Lama rawat dari pasien rawat inap rumah sakit Siti Khodijah digolongkan menjadi 3 kelompok, yaitu :

1) 1 minggu

2) 2 minggu

3) > 2 minggu

\subsection{Analisis Data}

Metode analisis data yang digunakan adalah sebagai berikut :

- Analisis data deskriptif, untuk mengetahui karakteristik pasien.

- Uji Chi-Square, untuk mengetahui :

1. hubungan antara jenis penyakit dengan jenis kelamin.

2. hubungan antara jenis penyakit dengan usia.

\section{Hasil dan Pembahasan}

\section{Karakteristik Jenis Kelamin Pasien Rawat Inap}

Untuk karakteristik jenis kelamin dapat dilihat pada grafik batang (grafik 4.1) berikut :

Dari histogram jenis kelamin pasien rawat inap, dapat dilihat jenis kelamin pasien yang paling banyak rawat inap di rumah sakit Siti Khodijah ini adalah pasien yang berjenis kelamin laki-laki sebanyak 4.097 pasien, sedangkan untuk pasien yang berjenis kelamin perempuan sebanyak 3.616 pasien.

\section{Karakteristik Usia Pasien Rawat Inap}

Untuk karakteristik usia pasien rawat inap dapat dilihat pada grafik 4.2. Berdasarkan grafik batang usia pasien rawat inap, dapat kita lihat pasien rawat inap yang dirawat di rumah sakit Siti Khodijah paling banyak adalah pasien yang berusia balita yaitu antara umur $0-5$ tahun sebanyak 2632 pasien, sedangkan untuk pasien rawat inap yang paling sedikit di rawat di rumah sakit ini yaitu pasien usia lansia sebanyak 438 pasien. 
19 | Penerapan Metode Tabel Kontingensi Untuk Mengetahui Hubungan Antara Jenis Penyakit, Jenis Kelamin, Usia, Lama Rawat dan Keadaan Keluar Pasien

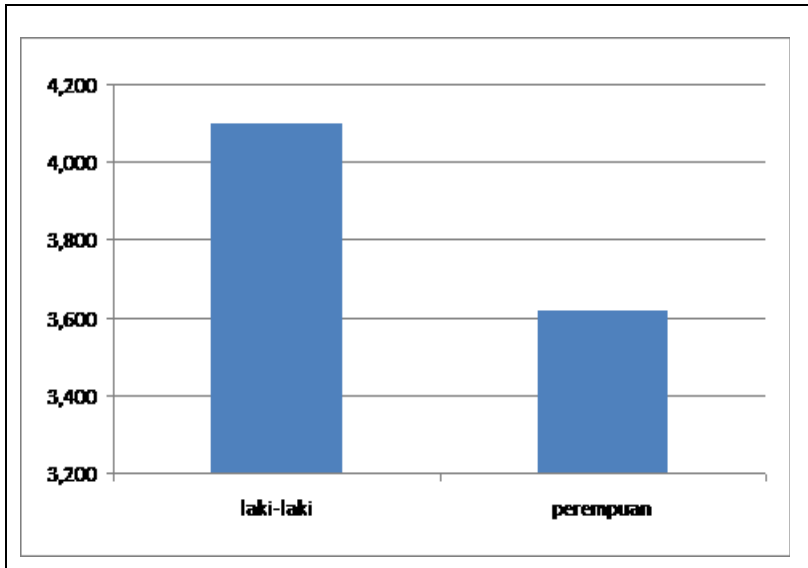

Grafik 4.1. Jenis Kelamin Pasien Rawat Inap

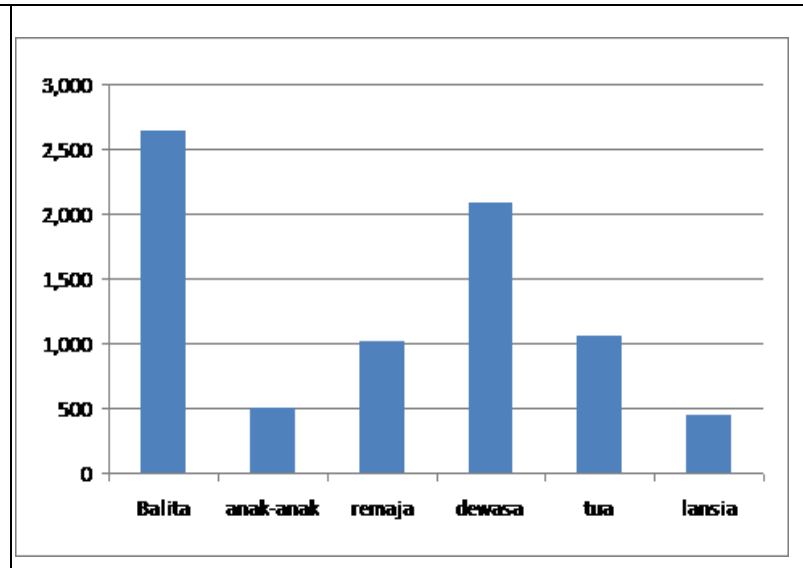

Grafik 4.2. Usia Pasien Rawat Inap

\section{Karakteristik Lama Rawat Pasien Rawat Inap.}

Untuk karakteristik lama rawat pasien rawat inap dapat dilihat pada grafik 4.3. Dari grafik batang lama perawatan pasien rawat inap diatas, dapat dilihat pasien rawat inap di rumah sakit Siti Khodijah yang dirawat selama 1 minggu paling banyak yaitu 7.007 pasien, sedangkan untuk lama rawat > 2 minggu paling sedikit yaitu hanya 103 pasien.

\section{Karakteristik Keadaan Keluar Pasien Rawat Inap}

Untuk karakteristik keadaan keluar pasien rawat inap dapat dilihat pada grafik 4.4. Dari grafik batang keadaan keluar pasien rawat inap diatas, dapat dilihat keluar dalam keadaan sembuh paling banyak yaitu 6.037 pasien dan keluar dalam keadaan dirujuk ke rumah sakit lain adalah paling sedikit yaitu 131 pasien.

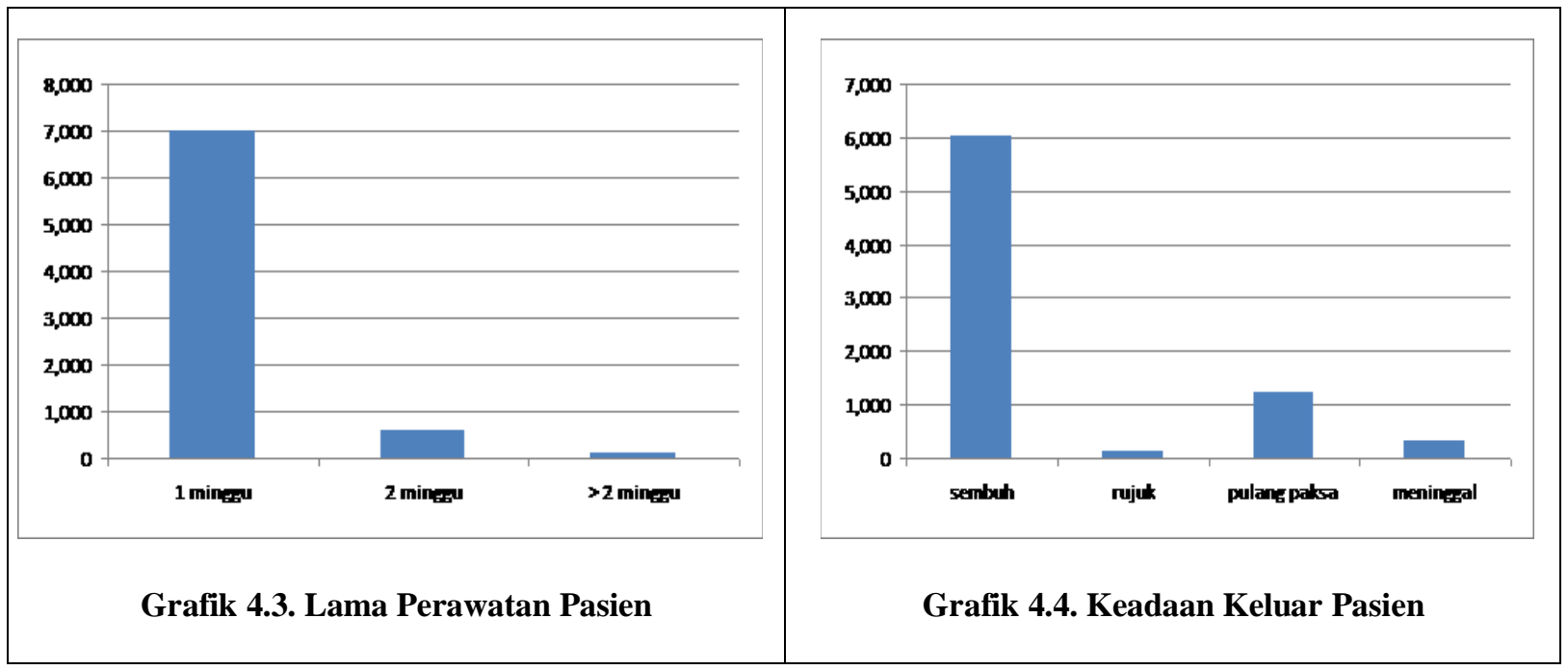


Karakteristik Jenis Penyakit dengan Jenis Kelamin Pasien Rawat Inap

Untuk karakteristik jenis penyakit dengan jenis kelamin pasien rawat inap maka dapat kita lihat pada tabel kontingensi 4.5 berikut :

Jumlah pasien rawat inap berdasarkan jenis penyakit dengan jenis kelamin pasien, dapat dilihat pada grafik batang berikut :

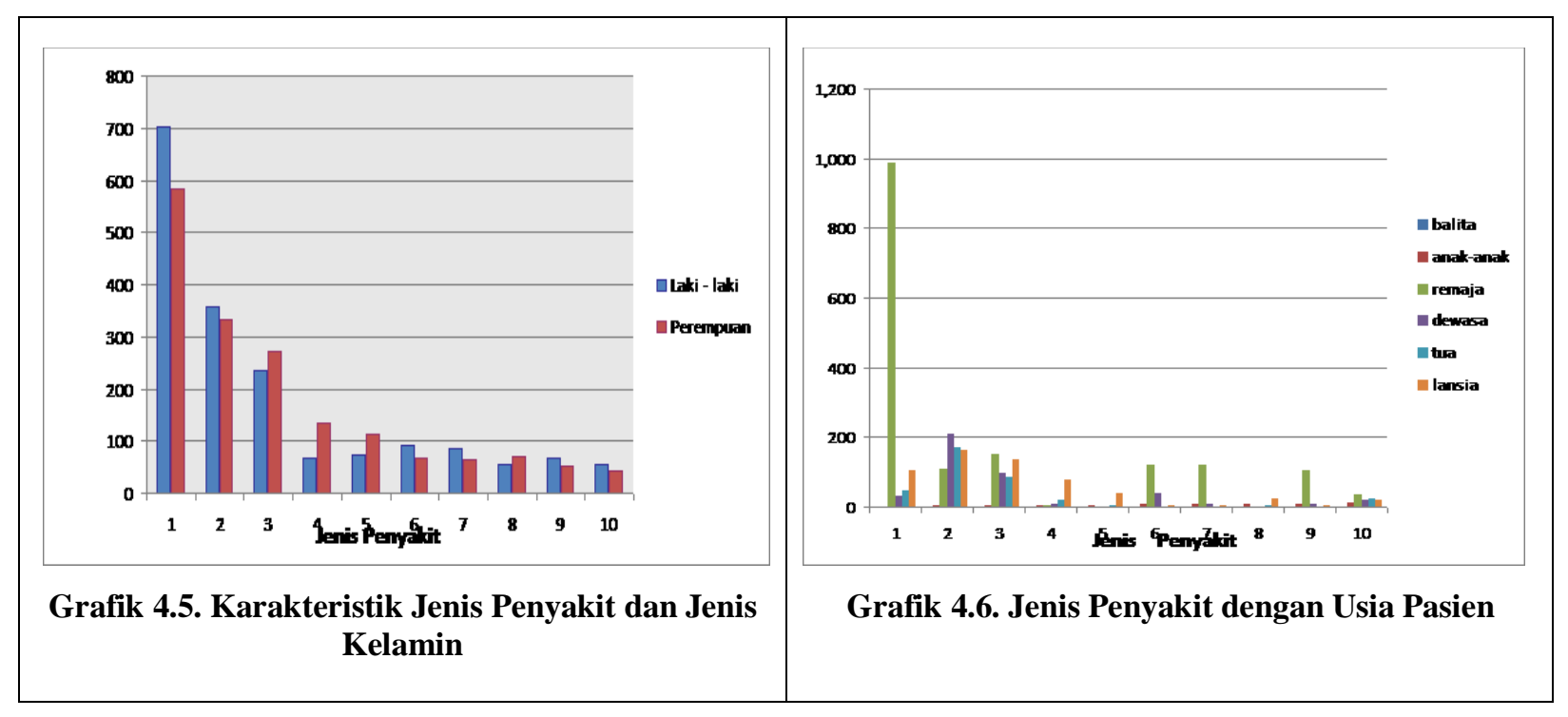

Dari histogram jenis penyakit dengan jenis kelamin pasien rawat inap di atas, maka dapat kita lihat pasien yang dirawat inap di rumah sakit Siti Khodijah banyak yang menderita penyakit GE atau yang lebih dikenal masyarakat dengan penyakit diare yaitu sebanyak 1.284 pasien. Dari 10 jenis penyakit yang paling sering diderita oleh pasien rawat inap ini adalah banyak yang berjenis kelamin laki - laki, sedangkan untuk jenis kelamin perempuan banyak yang menderita penyakit typhoid fever atau penyakit typhus, gastritis atau penyakit nyeri perut, diabetes mellitus atau kencing manis dan hypertensi atau penyakit tekanan darah tinggi.

\section{Karakteristik Jenis Penyakit dengan Usia Pasien Rawat Inap}

Untuk karateristik jenis penyakit dengan usia pasien rawat inap maka dapat dilihat pada grafik 4.6 :

Dari grafik batang jenis penyakit dengan usia pasien rawat inap di atas, dapat dilihat usia pasien balita lebih banyak dan penyakit yang paling banyak diderita adalah GE atau yang dikenal dengan penyakit diare yaitu sebanyak 987 pasien, paling sedikit adalah penderita gastritis atau nyeri perut yaitu sebanyak 5 pasien. Jenis penyakit GE (diare), DHF (demam berdarah), typhoid fever (typhus), dan gastritis (nyeri perut) penderita banyak dari semua kelompok usia. Namun untuk penyakit diabetes mellitus (kencing manis) dan hypertensi (tekanan darah tinggi) banyak diderita kelompok usia dewasa, tua dan lansia.

\section{Hubungan Antara Jenis Penyakit dengan Usia Pasien Rawat Inap}

Hipotesis

$H_{0} \quad$ : Jenis penyakit dengan usia pasien rawat inap independen

$H_{1}$ : Jenis penyakit dengan usia pasien rawat inap dependen 
21 | Tabel Kontingensi Untuk Mengetahui Hubungan Antara Jenis Penyakit, Jenis Kelamin, Usia, Lama Rawat dan Keadaan Keluar Pasien

$>$ Nilai frekuensi harapan $\left(E_{i j}\right)$

Tabel 4.1. : Tabel Nilai Frekuensi Amatan dan Frekuensi Harapan Jenis Penyakit dengan Usia Pasien Rawat Inap

\begin{tabular}{|c|c|c|c|c|c|c|c|c|c|c|c|}
\hline \multirow[t]{2}{*}{ Usia } & \multicolumn{10}{|c|}{ Jenis Penyakit } & \multirow[t]{2}{*}{ Total } \\
\hline & 1 & 2 & 3 & 4 & 5 & 6 & 7 & 8 & 9 & 10 & \\
\hline \multirow[t]{2}{*}{1} & 987 & 107 & 151 & 5 & 0 & 119 & 121 & 0 & 106 & 35 & 1631 \\
\hline & 595,11 & 319,80 & 235,91 & 92,70 & 87,13 & 74,16 & 68,13 & 57,01 & 55,15 & 45,88 & 1630,98 \\
\hline \multirow[t]{2}{*}{2} & 32 & 209 & 95 & 7 & 0 & 38 & 7 & 0 & 9 & 19 & 416 \\
\hline & 151,79 & 81,57 & 60,17 & 23,64 & 22,22 & 18,91 & 17,38 & 14,54 & 14,07 & 11,70 & 415,99 \\
\hline \multirow[t]{2}{*}{3} & 48 & 172 & 84 & 20 & 2 & 1 & 0 & 2 & 1 & 22 & 352 \\
\hline & 128,44 & 69,02 & 50,91 & 20,01 & 18,81 & 16 & 14,70 & 12,30 & 11,90 & 9,90 & 351,99 \\
\hline \multirow[t]{2}{*}{4} & 103 & 163 & 135 & 76 & 40 & 2 & 5 & 22 & 2 & 20 & 568 \\
\hline & 207,25 & 111,37 & 82,16 & 32,28 & 30,34 & 25,83 & 23,73 & 19,85 & 19,21 & 15,98 & 568 \\
\hline \multirow[t]{2}{*}{5} & 69 & 35 & 39 & 54 & 110 & 0 & 11 & 69 & 1 & 3 & 391 \\
\hline & 142,67 & 76,67 & 56,56 & 22,22 & 20,89 & 17,78 & 16,33 & 13,67 & 13,22 & 11,00 & 391,01 \\
\hline \multirow[t]{2}{*}{6} & 45 & 4 & 5 & 38 & 36 & 0 & 3 & 30 & 0 & 0 & 161 \\
\hline & 58,75 & 31,57 & 23,29 & 9,15 & 8,60 & 7,32 & 6,73 & 5,63 & 5,44 & 4,53 & 161,01 \\
\hline \multirow[t]{2}{*}{ Total } & 1284 & 690 & 509 & 200 & 188 & 160 & 147 & 123 & 119 & 99 & 3519 \\
\hline & 1284,01 & 690 & 509 & 200 & 187,99 & 160 & 147 & 123 & 118,99 & 98,99 & 3518,98 \\
\hline
\end{tabular}

$>$ Daerah kritis

Tingkat kesalahan yang digunakan adalah sebesar $5 \%$.

Derajat bebas $(\mathrm{db}) \quad=(10-1)(6-1)=45, \quad$ Nilai $x_{\text {tabel }}^{2}=67,50$

$>$ Nilai Chi-Square $\left(x^{2}\right)$

$x^{2}=\sum_{i=1}^{b} \sum_{j=1}^{k} \frac{(O i j-E i j)^{2}}{E i j}$

$x^{2}=\sum_{i=1}^{6} \sum_{j=1}^{10} \frac{(987-595.11)^{2}}{595,11}+\frac{(32-151.79)^{2}}{151.79}+\ldots . .+\frac{(0-4.53)^{2}}{4.53}=2794,975$

Tabel 4.2 : Tabel Nilai Chi-Square Jenis Penyakit dengan Usia Pasien Rawat Inap

\begin{tabular}{|c|c|c|c|c|c|c|c|c|c|c|c|}
\hline \multirow{2}{*}{ Usia } & \multicolumn{9}{|c|}{ Jenis Penyakit } & \multirow{2}{*}{ Total } \\
\cline { 2 - 11 } & $\mathbf{1}$ & $\mathbf{2}$ & $\mathbf{3}$ & $\mathbf{4}$ & $\mathbf{5}$ & $\mathbf{6}$ & $\mathbf{7}$ & $\mathbf{8}$ & $\mathbf{9}$ & $\mathbf{1 0}$ & \\
\hline $\mathbf{1}$ & 258.06 & 141.604 & 30.563 & 82.966 & 87.135 & 27.116 & 41.023 & 57.009 & 46.873 & 2.582 & 774.931 \\
\hline & 16.064 & -11.900 & -5.528 & -9.109 & -9.335 & 5.207 & 6.405 & -7.550 & 6.846 & -1.607 & \\
\hline $\mathbf{2}$ & 94.535 & 199.081 & 20.159 & 11.716 & 22.224 & 19.258 & 6.197 & 14.540 & 1.826 & 4.549 & 394.085 \\
\hline & -9.723 & 14.110 & 4.490 & -3.423 & -4.714 & 4.388 & -2.489 & -3.813 & -1.351 & 2.133 & \\
\hline $\mathbf{3}$ & 50.375 & 153.651 & 21.5 & 0 & 15.018 & 14.067 & 14.704 & 8.629 & 9.987 & 14.778 & 302.709 \\
\hline & -7.098 & 12.396 & 4.637 & -0.001 & -3.875 & -3.751 & -3.835 & -2.937 & -3.160 & 3.844 & \\
\hline $\mathbf{4}$ & 52.439 & 23.932 & 33.988 & 59.206 & 3.072 & 21.980 & 14.781 & 0.232 & 15.416 & 1.102 & 226.058 \\
\hline & -7.241 & 4.892 & 5.830 & 7.695 & 1.753 & -4.688 & -3.845 & 0.482 & -3.926 & 1.006 & \\
\hline $\mathbf{5}$ & 38.038 & 22.645 & 5.449 & 45.442 & 380.144 & 17.778 & 1.741 & 224.033 & 11.298 & 5.818 & 752.386 \\
\hline & -6.168 & -4.759 & -2.334 & 6.741 & 19.497 & -4.216 & -1.320 & 14.968 & -3.361 & -2.412 & \\
\hline $\mathbf{6}$ & 3.216 & 24.075 & 14.361 & 90.959 & 97.276 & 7.320 & 2.064 & 105.558 & 5.444 & 4.529 & 344.802 \\
\hline & -1.793 & -1.907 & -3.790 & 9.537 & 9.342 & -2.706 & -1.437 & 10.274 & -2.333 & -2.128 & \\
\hline Total & 496.663 & 564.869 & 126.02 & 290.289 & 594.869 & 107.519 & 80.51 & 410.001 & 90.844 & 33.268 & 2794.975 \\
\hline
\end{tabular}

Keterangan : $(*)$ nilai standar residual 
Kesimpulan

Nilai $x_{\text {hitung jauh lebih besar dari }}^{2} x_{\text {tabel }}^{2}$ maka $H_{0}$ ditolak yang berarti bahwa jenis kelamin dan usia pasien rawat inap tidak saling bebas dan keduanya saling berkaitan. Hal ini dapat juga dilihat dari nilai standar residual antara jenis penyakit dengan usia pasien rawat inap dimana hampir seluruh nilainya di luar interval $-1,96$ sampai 1,96. Namun ada jenis penyakit tertentu yang tidak signifikan hubungannya dengan usia pasien yaitu untuk jenis penyakit gastritis pada usia remaja, penyakit hypertensi pada usia dewasa, penyakit pneumonia pada usia tua dan lansia, penyakit step pada usia anak - anak dan juga penyakit FUO (demam) pada usia dewasa.

Pada usia tertentu ada kecenderungan untuk menderita penyakit tertentu pula. Seperti pada penyakit FUO atau penyakit demam yang tidak diketahui sebabnya, dimana penderitanya banyak pada usia balita, hal ini mungkin dikarenakan kondisi tubuh pada usia balita yang tidak stabil sehingga rentan terhadap penyakit ini. Begitu juga dengan penyakit hipertensi atau penyakit tekanan darah tinggi dan penyakit diabetes mellitus atau penyakit kencing manis, kebanyakan pasien yang menderita penyakit ini adalah pasien yang berusia 25 tahun keatas. Penyakit tekanan darah tinggi ini disebabkan kadar hemoglobin $(\mathrm{Hb})$ dalam darah tinggi, karena cara mengkonsumsi makanan yang kurang seimbang sedangkan untuk penyakit kencing manis ini bergantung pada insulin dan penyakit ini disebabkan oleh karena kadar gula dalam tubuh yang berlebihan sehingga mengganggu proses bekerja dari organ organ tubuh.

\section{Hubungan antara jenis penyakit dengan jenis kelamin pasien rawat inap}

$>$ Hipotesis

$$
\begin{array}{ll}
H_{0} & : \text { Jenis penyakit dengan jenis kelamin pasien rawat inap independen } \\
H_{1} & : \text { Jenis penyakit dengan usia kelamin rawat inap dependen }
\end{array}
$$

$>$ Nilai frekuensi harapan $\left(E_{i j}\right)$

Tabel 4.3. : Tabel Nilai Frekuensi Amatan dan Frekuensi Harapan Jenis Penyakit dengan Jenis Kelamin

\begin{tabular}{|c|c|c|c|c|c|c|c|c|c|c|c|}
\hline \multirow[t]{2}{*}{ JK } & \multicolumn{10}{|c|}{ Jenis Penyakit } & \multirow[t]{2}{*}{ Total } \\
\hline & 1 & 2 & 3 & 4 & 5 & 6 & 7 & 8 & 9 & 10 & \\
\hline \multirow[t]{2}{*}{1} & 702 & 358 & 236 & 67 & 74 & 93 & 84 & 54 & 66 & 55 & \multirow[t]{2}{*}{1789} \\
\hline & 652.76 & 350.78 & 258.77 & 101.68 & 95.58 & 81.34 & 74.73 & $\begin{array}{l}62.53 \\
\end{array}$ & $\begin{array}{l}60.50 \\
\end{array}$ & 50.33 & \\
\hline \multirow[t]{2}{*}{2} & 582 & 332 & 273 & 133 & 114 & 67 & 63 & 69 & 53 & 44 & \multirow[t]{2}{*}{1730} \\
\hline & 631.24 & 339.22 & 250.23 & 98.32 & 92.42 & 78.66 & 72.27 & 60.47 & 58.50 & 48.67 & \\
\hline Total & 1284 & 690 & 509 & 200 & 188 & 160 & 147 & 123 & 119 & 99 & 3519 \\
\hline
\end{tabular}
Pasien Rawat Inap

Daerah kritis

Tingkat kesalahan yang digunakan adalah sebesar $5 \%$

Derajat bebas $(\mathrm{db}) \quad=(10-1)(2-1)$

$$
=9
$$

$x_{\text {tabel }}^{2}=16,919$

$>$ Nilai Chi-Square $\left(x^{2}\right)$

$$
\begin{aligned}
x^{2} & =\sum_{i=1}^{b} \sum_{j=1}^{k} \frac{(O i j-E i j)^{2}}{E i j} \\
x^{2} & =\sum_{i=1}^{2} \sum_{j=1}^{10} \frac{(702-65276)^{2}}{65276}+\frac{(582-631.24)^{2}}{631.24}+\ldots .+\frac{(44-48.67)^{2}}{48.67} \\
& =55,898
\end{aligned}
$$


23 | Tabel Kontingensi Untuk Mengetahui Hubungan Antara Jenis Penyakit, Jenis Kelamin, Usia, Lama Rawat dan Keadaan Keluar Pasien

Tabel 4.4. : Tabel Nilai Chi-Square Jenis Penyakit dengan Jenis Kelamin Pasien Rawat Inap

\begin{tabular}{|c|c|c|c|c|c|c|c|c|c|c|c|}
\hline \multirow[t]{2}{*}{ JK } & \multicolumn{10}{|c|}{ Jenis Penyakit } & \multirow[t]{2}{*}{ Total } \\
\hline & 1 & 2 & 3 & 4 & 5 & 6 & 7 & 8 & 9 & 10 & \\
\hline \multirow[t]{2}{*}{1} & 3.714 & 0.148 & 2.003 & 11.826 & 4.871 & 1.671 & 1.149 & 1.164 & 0.5 & 0.433 & \multirow[t]{2}{*}{27.479} \\
\hline & 1.927 & 0.385 & -1.415 & -3.439 & -2.207 & 1.293 & 1.072 & -1.079 & 0.707 & 0.658 & \\
\hline \multirow[t]{2}{*}{2} & 3.84 & 0.153 & 2.071 & 12.23 & 5.037 & 1.728 & 1.188 & 1.204 & 0.518 & 0.448 & \multirow[t]{2}{*}{28.417} \\
\hline & -1.960 & -0.39 & 1.439 & 3.497 & 2.244 & -1.315 & -1.090 & 1.097 & -0.719 & -0.669 & \\
\hline Tot & 7.554 & 0.301 & 4.074 & 24.056 & 9.908 & 3.399 & 2.337 & 2.368 & 1.018 & 0.881 & 55.898 \\
\hline
\end{tabular}

Keterangan :

(*) Nilai Standar Residual

\section{Kesimpulan}

Nilai $x_{\text {hitung }}^{2}>x_{\text {tabel }}^{2}$ maka $H_{0}$ ditolak yang berarti bahwa jenis penyakit dan jenis kelamin pasien rawat inap tidak saling bebas dan keduanya saling berkaitan. Sehingga dapat dikatakan bahwa pada jenis penyakit tertentu mempunyai kecenderungan jenis kelamin tertentu pula. Seperti halnya pada penyakit diabetes mellitus atau penyakit kencing manis penderitanya banyak yang berjenis kelamin perempuan hal ini disebabkan karena hormon progesteron yang ada pada tubuh perempuan susah mengolah kadar gula yang berlebihan.Namun kalau dilihat dari nilai standar residualnya belum signifikan karena banyak nilai yang ada dalam interval - 1,96 sampai 1,96. Adapun dependensi antara jenis penyakit dengan jenis kelamin ini yang paling signifikan adalah untuk jenis penyakit GE atau diare, gastritis dan diabetes mellitus.

\section{Hubungan antara lama rawat dengan keadaan keluar pasien rawat inap.}

Hipotesis

$H_{0} \quad$ : lama rawat dengan keadaan keluar pasien rawat inap independen

$H_{1} \quad$ : lama rawat dengan keadaan keluar pasien rawat inap dependen

Nilai frekuensi harapan $\left(E_{i j}\right)$

$$
E_{i j}=\frac{b_{i} k_{j}}{N}
$$

Tabel 4.5. : Tabel Nilai Frekuensi Amatan dan Frekuensi Harapan Lama Rawat dengan Keadaan Keluar Pasien Rawat Inap

\begin{tabular}{|c|c|c|c|c|}
\hline \multirow[t]{2}{*}{ Keadaan Keluar } & \multicolumn{3}{|c|}{ Lama Rawat } & \multirow[t]{2}{*}{ Total } \\
\hline & 1 Minggu & 2 Minggu & > 2 Minggu & \\
\hline \multirow[t]{2}{*}{ Sembuh } & 5497 & 471 & 69 & \multirow[t]{2}{*}{6037} \\
\hline & 5484.41 & 471.97 & 80.62 & \\
\hline \multirow[t]{2}{*}{ Rujuk } & 117 & 10 & 4 & \multirow[t]{2}{*}{131} \\
\hline & 119.01 & 10.24 & 1.75 & \\
\hline \multirow[t]{2}{*}{ Pulang Paksa } & 1105 & 95 & 19 & \multirow[t]{2}{*}{1219} \\
\hline & 1107.42 & 95.30 & 16.28 & \\
\hline \multirow[t]{2}{*}{ Meningggal } & 288 & 27 & 11 & \multirow[t]{2}{*}{326} \\
\hline & 296.16 & 25.49 & 4.35 & \\
\hline Total & 7007 & 603 & 103 & 7713 \\
\hline
\end{tabular}


Daerah kritis

Tingkat kesalahan yang digunakan adalah sebesar $5 \%$.

Derajat bebas $(\mathrm{db})=(3-1)(4-1)$

$=6$

$x_{\text {tabel }}^{2}=12,592$

Nilai Chi-Square $\left(x^{2}\right)$

$$
\begin{aligned}
& x^{2}=\sum_{i=1}^{b} \sum_{j=1}^{k} \frac{(O i j-E i j)^{2}}{E i j} \\
& x^{2}=\sum_{i=1}^{2} \sum_{j=1}^{10} \frac{(5497-5484.41)^{2}}{5484.41}+\frac{(117-119.01)^{2}}{119.01}+\ldots .+\frac{(11-4.35)^{2}}{4.35}=15,564
\end{aligned}
$$

Tabel 4.6. : Tabel Nilai Chi-Square Lama Rawat dengan Keadaan Keluar

\begin{tabular}{|c|c|c|c|c|}
\hline \multirow[t]{2}{*}{ Keadaan Keluar } & \multicolumn{3}{|c|}{ Lama Rawat } & \multirow[t]{2}{*}{ Total } \\
\hline & 1 Minggu & 2 Minggu & > 2 Minggu & \\
\hline \multirow[t]{2}{*}{ Sembuh } & 0.029 & 0.002 & 1.674 & \multirow[t]{2}{*}{1.705} \\
\hline & 0.170 & -0.044 & -1.294 & \\
\hline \multirow[t]{2}{*}{ Rujuk } & 0.034 & 0.006 & 2.895 & \multirow[t]{2}{*}{2.935} \\
\hline & -0.184 & -0.075 & 1.701 & \\
\hline \multirow[t]{2}{*}{ Pulang Paksa } & 0.005 & 0.001 & 0.455 & \multirow[t]{2}{*}{0.461} \\
\hline & -0.072 & -0.030 & 0.674 & \\
\hline \multirow[t]{2}{*}{ Meningggal } & 0.225 & 0.090 & 10.148 & \multirow[t]{2}{*}{10.463} \\
\hline & -0.474 & 0.299 & 3.185 & \\
\hline Total & 0.293 & 0.099 & 15.172 & 15.564 \\
\hline
\end{tabular}
Pasien Rawat Inap.

Keterangan :

(*) Nilai Standar Residual

Nilai $x_{\text {hitung }}^{2}>x_{\text {tabel }}^{2}$ maka $H_{0}$ ditolak yang berarti bahwa lama rawat dan keadaan keluar pasien rawat inap tidak saling bebas dan keduanya saling berkaitan. Sehingga dapat dikatakan pasien dengan lama rawat tertentu maka keadaan keluarnya juga tertentu pula.

Namun kalau dilihat dari nilai standar residualnya belum signifikan karena banyak nilainya di dalam interval - 1,96 sampai 1,96. Untuk hal ini dependensi yang paling signifikan antara lama rawat dengan keadaan keluar pasien adalah lama rawat lebih > 2 minggu dan keluar dalam keadaan di rujuk ke rumah sakit lain dan meninggal. Sehingga dapat dikatakan pasien dengan lama rawat tertentu maka keadaan keluarnya juga tertentu pula.

\section{KESIMPULAN}

1. Pasien yang paling banyak rawat inap di rumah sakit Siti Khodijah adalah pasien laki - laki, usia pasien yang paling banyak dirawat inap adalah usia balita yaitu sebanyak 1.631 pasien. Dari 10 jenis penyakit yang paling sering diderita oleh pasien rawat inap adalah penyakit GE atau yang lebih dikenal dengan penyakit diare dan yang paling sedikit adalah penyakit FUO atau penyakit demam yang tidak diketahui penyebabnya. Pasien yang dirawat inap di rumah sakit banyak yang keluar dalam keadaan sembuh yaitu sebanyak 6.037 pasien dari 7.713 pasien dirawat inap di rumah sakit Siti Khodijah selama tahun.

2. Dari hasil uji statistik chi-square antara jenis penyakit dengan usia pasien yang dirawat inap di rumah sakit Siti Khodijah tidak saling bebas atau keduanya mempunyai hubungan. Sehingga dapat disimpulkan bahwa pada usia tertentu ada kecenderungan untuk menderita penyakit tertentu pula. Namun ada jenis penyakit tertentu yang tidak signifikan hubungannya dengan usia pasien yaitu untuk jenis penyakit gastritis pada usia 


\section{5 | Tabel Kontingensi Untuk Mengetahui Hubungan Antara Jenis Penyakit, Jenis Kelamin, Usia, Lama Rawat dan Keadaan Keluar Pasien}

remaja, penyakit hipertensi pada usia dewasa, penyakit pneumonia pada usia tua dan lansia, penyakit step pada usia anak - anak dan juga penyakit FUO pada usia dewasa.

3. Hasil uji statistik chi-square untuk jenis penyakit dengan jenis kelamin pasien rawat inap di rumah sakit Siti Khodijah hasilnya tidak saling bebas atau keduanya saling berhubungan. Sehingga dapat dikatakan pada jenis kelamin tertentu ada kecenderungan untuk menderita penyakit tertentu pula. Adapun hubungan antara jenis penyakit dengan jenis kelamin ini yang paling signifikan adalah untuk penyakit GE atau diare, Gastritis dan FUO.

4. Hasil uji statistik chi-square untuk lama rawat pasien dengan keadaan keluar pasien saat dirawat inap di rumah sakit Siti Khodijah tidak saling bebas atau kedua variabel ini saling berhubungan. Sehingga dapat dikatakan pasien dengan lama rawat tertentu maka keadaan keluarnya juga tertentu pula. Untuk hal ini yang hubungannya paling signifikan antara lama rawat dengan keadaan keluar pasien adalah lama rawat lebih > 2 minggu dan keluar dalam keadaan meninggal.

\section{Daftar Pustaka}

The Analysis of Contingency Tables. Brian Everitt. Chapman and Hall. Second Edition. 1992, 164 pages. Rumah sakit, id. Wikipedia.org/wiki/rumah_sakit.

Rumah Sakit, bankdata.depkes.go.id/profil/INDO97/CONTENS/SUMBER/RS.htm

Tri, A, 2000, Analisa Ragam Multivariate Untuk Efisiensi Pemakaian Tempat Tidur di RSUD Dr. Soetomo

Surabaya Tahun 1998 - 1999, Laporan Kerja Praktek Jurusan Statistika, Surabaya, ITS

Usman, Husaini dan Akbar, P.S, 2004, Metodologi Penelitian Sosial, Bumi Aksara

Walpole, R.E dan Myers, R, H, 1995, Ilmu Peluang dan Statistika Untuk Insinyur dan Ilmuwan, Edisi k- 4, Bandung, Penerbit ITB. 
26| Wara Pramesti 